\title{
MR Manifestations of Vertebral Artery Injuries in Cervical Spine Trauma'
}

\author{
Jeong Sik Yu, M.D., Tae Sub Chung, M.D., Young Soo Kim, M.D. ${ }^{2}$ \\ Yong Eun Cho, M.D. ${ }^{2}$, Byung Chul Kang, M.D., Dong Ik Kim, M.D.
}

\begin{abstract}
Purpose : To assess the diagnostic efficacy of magnetic resonance (MR) imaging in the detection of a vertebral artery injury occurring from major cervical spine trauma.

Materials and Methods : Conventional MR findings of 63 patients and 63 control subjects were compared to detect a possible change in the vertebral arteries resulted from trauma. Plain films, CT and clinical records were also reviewed to correlate the degree of cervical spine injury with vascular change.

Results : Nine cases of absent flow signals in vessel lumen were observed in eight patients and one was observed in the control group. Patients more frequently demonstrated other abnormalities such as intraluminal linear signals $(n=$ 3 ) or focal luminal narrowing $(n=9)$ but there was no statistical significance. There was a close relationship between degree of cord damage and occlusion of the vertebral artery.

Conclusion : Conventional MR imaging is useful in the detection of vertebral artery occlusion resulting from cervical spine trauma.
\end{abstract}

\author{
Index Words : Arteries, vertebral \\ Spine, injuries \\ Spine, MR
}

Acute fracture-dislocation of the cervical spine has long been known to be an important causative event of vertebral artery injury (1). However, in the early stage of admission, it is not easy to clearly recognize this injury by physical examination of an unstable patient with injuries such as cord contusion and vertebral fracture, with or without head trauma. In the later period of stabilization, the possibility of vessel injury would not be suggested until a certain sign of severe vertebrobasilar insufficiency developed. Thus, further radiological investigation for possible vessel damage might not be undertaken. Recently, magnetic resonance(MR) imaging has been generally applied to cervical spine trauma patients for a detailed evaluation of spinal cord injuries. Concomitant or incidental soft tissue changes have been found and easily outlined, and suspected but clin-

\footnotetext{
'Department ofDiagnostic Radiology, Yonsei University College of Medicine

${ }^{2}$ Department of Neurosurgery, Yonsei University College of Medicine

Received June 28,1996; Accepted August 28,1996

Address reprint requests to : Jeong Sik Yu, M.D., Department of Radiology,

Yong Dong Severance Hospital, \#146-92, Dokok-Dong, Kangnam-Ku, Seoul,

135-270, Korea.

Tel. 82-2-3450-3515, Fax. 82-2-562-5472
}

ically occult vertebral artery changes can be revealed by these MR images $(2,3)$. In the literature, we were able to find only a few MR imaging reports concerning this vessel problem $(3-8)$.

This study was undertaken to assess the efficacy of routine MR imaging in the detection of vertebral artery injuries through a review of MR images in major nonpenetrating cervical spine trauma patients.

\section{MATERIALS and METHODS}

From December 1993 to October 1995, MR imaging was used at our institute to examine sixty-three cervical spine trauma patients(with fracture, dislocation or subluxation injury) for initial diagnosis or follow up evaluation of clinically suggested cervical cord injury. The study population included 41 male and 22 female patients, aged $20-59$ years (mean, 36.7 ).

In all patients, MR images were routinely obtained on a 1.0T imager(Magnetom 42sp ; Siemens, Erlangen, Germany) from one to 110 days(mean, 27 days) after injury. Neck surface coils were routinely used. All MR imaging examination was performed with a $128-256 \times$ 
256 matrix and $5-\mathrm{mm}$ section thickness and a $0.2 \mathrm{~mm}$ interslice gap. In all patients, spin echo T1-weighted sagittal and gradient-recalled echo(GRE) sagittal and axial images were obtained. Our current MR imaging protocol includes a T1-weighted sequence of 550/15 (repetition time [TR] msec/echo time [TE] msec), and a gradient echo [GRE] sequence of $510 / 12$ with $50^{\circ}$ flip angle. MR angiography was not performed initially in all patients. All studies were assessed by two radiologists for the following diagnostic points of vertebral artery damage : [1] absent or poorly visualized flow-related signal ; [2] an abruptly narrowed flow signal more than $50 \%$ of short diameter with a deformed contour rather than the usual round shape in axial section ; [3] abnormal traversing linear signal in axial views ; [4] abnormal location of vertebral artery flow signal outside the osteofibrous tunnel. Because the GRE sequence employed in this study allows a bright signal for fast flowing blood on axial section, the detailed evaluation of these vessels was limited to just V2 segments in the axial views, with sagittal views for reference. This was to minimize the possibility of a false-positive interpret- ation related to inherent artifacts of gradient echo MR imaging including slow flowing blood during the diastolic phase or the angulation of flow direction in V1 or V3 segments. For a positive reading, focal vascular lesions had to be within two vertebral levels of the major extravascular injury site.

For comparison, another $63 \mathrm{MR}$ images of the control group (aged 25-63 years, mean 44.8) of non-traumatic, herniated cervical disk patients were at the same time randomly sampled and reviewed. The results of positive findings and pattern interpretation of vertebral artery injuries were recorded after consensus.

One to fourteen days(mean 5 days) after initial MRI, additional MR angiography(MRA) $(n=6)$ and digital subtraction angiography(DSA) $(n=3)$ were performed on patients with positive MR findings to confirm vessel injury. Two-dimensional time-of-flight(TR/TE/ $F A=25 / 9 /$ $35^{\circ}$ ) MRA studies were obtained on a 1.5T imager (Magnetom VISION ; Siemens, Erlangen, Germany). Initial plain radiographic films $(n=63)$ and computed tomographic images $(n=59)$ were reviewed for the assessment of surrounding bony structures. The medical

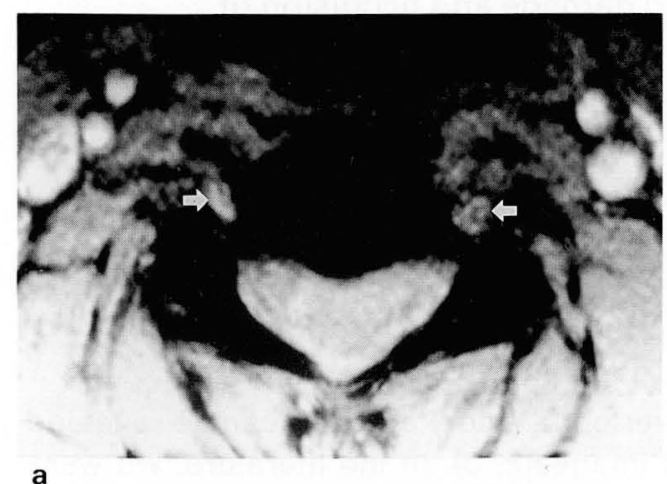

a

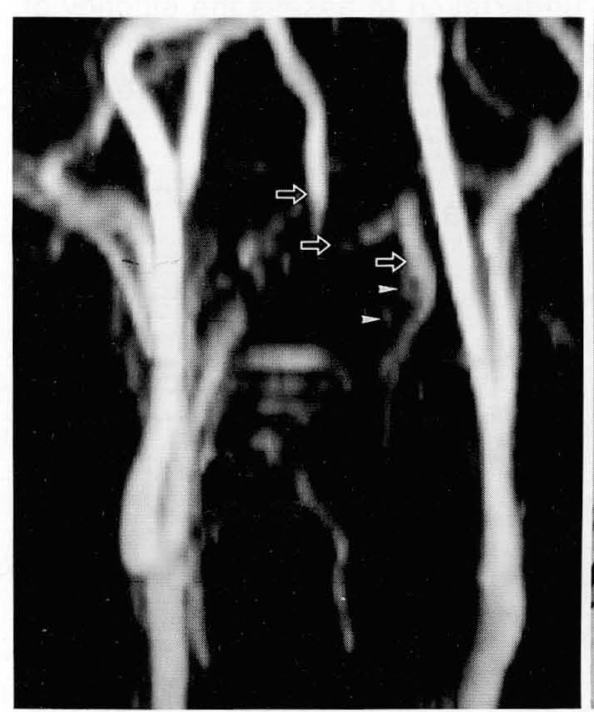

b

Fig. 1. Bilateral vertebral artery occlusion in 45-year-old man with quadriplegia due to a C5-C6 fracture and dislocation injury.

a. Axial gradient echo MR image $\left(510 / 12 / 50^{\circ}\right)$ obtained at C- 5 demonstrates the absence of flow-related signal usually expected for vertebral arteries(arrows).

b. Right frontal oblique view, two-dimensional time-of-flight MR angiogram reveals nonvisualization of left vertebral artery of proximal V2 segment; distal V2 and V3 segments(open arrows) are reconstituted by collaterals from muscular arteries(arrowheads). The proximal V2 segment of right vertebral artery was not visualized also in other projections(not shown).

c. Anteroposterior view of right vertebral angiogram definitively shows proximal occlusion of right vertebral artery(arrows) with collateral reconstitution of distal segments supplied by muscular branches of ascending cervical artery(open arrows). d. Axial cranial CT scan shows large infarction(arrows) in left superior cerebellar artery territory suggesting the relation to the vertebrobasilar arterial flow insufficiency.

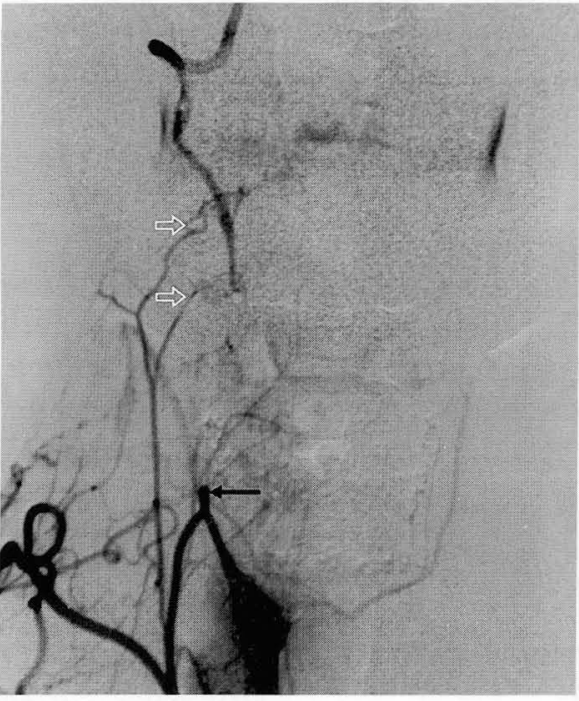

C

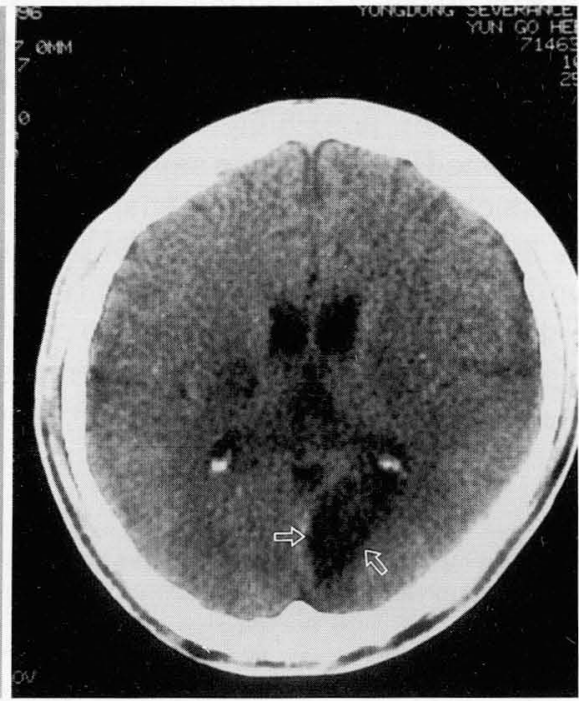

d 
records of these patients were also reviewed to search for clinical signs including the degree of cord injury. Initial prereduction subluxation or dislocation plain films were available for only 24 patients, however, so quadriplegia or paraplegia were clinically considered to be signs of severe cervical spine trauma. The chi-square test was used to elucidate the relationship between the degree of trauma and the vascular injury.

\section{RESULTS}

Twenty-three abnormal findings were identified in the 126 vertebral arteries of 63 patients and eight in the control group. Two unilaterally tiny vertebral foramina in each group were observed through the subsequent CT reviews but were not included in statistical analysis (Table 1). Nine vertebral arteries of eight patients and one of one in the control group showed absence or poor blood flow on initial reviews of MR images(Fig. 1,
2). Patients more frequently demonstrated other abnormalities such as intraluminal linear signals $(n=3)$ or focal luminal narrowing $(n=9)$ but there was no statistical significance(Fig. 3,4). Subsequent MRA and DSA were helpful in confirming the complete occlusion of vertebral arteries in five patients with no flow signals in six vertebral arteries(including one patient with bilateral occlusion) (Fig. 1, 2). In one patient with absent flow signal in the unilateral vertebral artery, MRA showed an intact flow signal in a 14-day-delayed scan, which suggested a spontaneous resolution of thrombosis during the 14-day interval.

On admission, all patients complained of non-specific or posterior neck pain, and 29 also complained of headache. Sixteen patients experienced loss of consciousness during the acute stage; in eight of these patients, the vertebral arteries on MR images were abnormal. A brain CT was obtained for evaluation of head injuries in 15 patients(including six who showed abnor-

Table 1. MR Manifestations of Vertebral arteries in the Patients of Cervical Spine Trauma Compared with Control Group.

\begin{tabular}{lccc}
\hline \hline & $\begin{array}{c}\text { Cervical Spine } \\
\text { Trauma } \\
(\mathrm{n}=122)^{*}\end{array}$ & $\begin{array}{c}\text { Control Group } \\
(\mathrm{n}=122)^{*}\end{array}$ & $\begin{array}{c}\text { Statistical Value } \\
\text { (by Fisher's } \\
\text { Exact Test) }\end{array}$ \\
\hline Absence or Poor Blood Flow Signal & 9 & 1 & $\mathrm{p}<.02$ \\
Intraluminal Traversing Linear Signal & 3 & 1 & $\mathrm{p}=.62$ \\
Focal Luminal Narrowing of Possible Dissection & 7 & 4 & $\mathrm{p}=.54$ \\
Luminal Narrowing from External Compression & 2 & 0 & $\mathrm{p}=.50$ \\
\hline Total & $21^{* *}$ & 6 & $\mathrm{p}<.02$ \\
\hline
\end{tabular}

*From the reviews of CT scans in the patients and in the control group, two cases of unilateral hypoplastic vertebral foramina in each group were demonstrated, and they were excluded in the statistical evaluation.

${ }^{* *}$ Total 21 abnormal flow signals were found in 18 patients including 3 cases of bilateral abnormality.

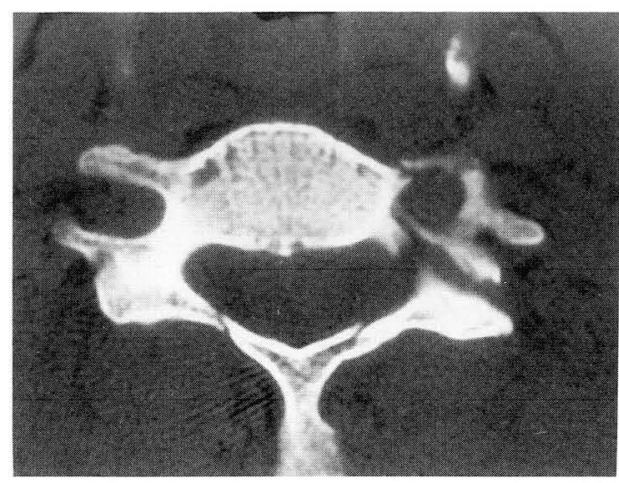

a

Fig. 2. Unilateral vertebral artery occlusion in a 36-year-old man with hypersthesia below C-5 level after motor vehicle accident.

a. CT image reveals C-5 left transverse process, pedicle and bilateral laminar fracture.

b. Axial gradient echo MR image $\left(510 / 12 / 50^{\circ}\right)$ obtained at C-5 demonstrates absence of flow signal in left vertebral artery(arrowheads).

c. Right frontal oblique view, two-dimensional time-of-flight MR angiogram reveals nonvisualization of left vertebral artery. The right vertebral artery is normally visualized (arrowheads). The right and left internal carotid arteries are incompletely seen due to exclusion from signal reconstruction from the base images (white arrows).

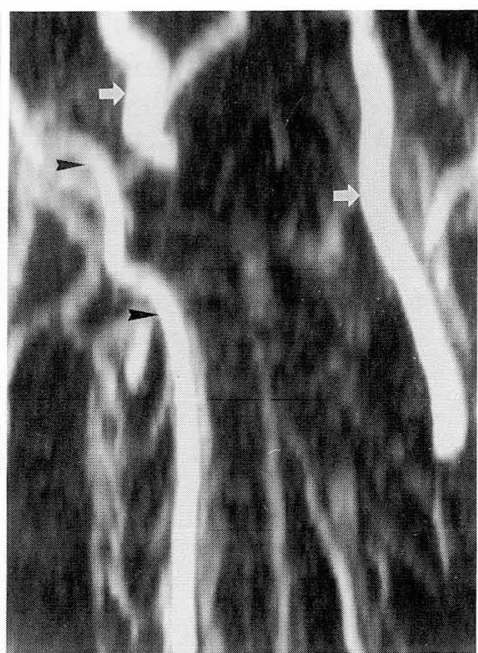

C 
mal vertebral arteries on MR images), but ischemic changes in the vertebrobasilar artery territory were visualized in only two patients with occluded vertebral arteries.

Compared with seven patients of the 43 with normal vessels $(16 \%)$, eight patients of the 18 with abnormal vertebral arteries $(42 \%)$ had quadriplegia or paraplegia. These differences were not statistically signifi$\operatorname{cant}(p=.06$; chi-square test). However, with occluded vertebral artery flow only( $n=9$ in eight patients), a significant correlation was found between the presence of a severe injury(six of eight patients with absent flow signal versus nine of 53 other patients) and the presence of an occlusion $(p<.02$; chi-square test). The incidence of left vertebral artery involvement $(n=14)$ exceeded that of the right $(n=7)$ and three cases showed bilateral vessel changes. Only one case showed a total bilateral absence of vertebral arterial flow signal (Fig. 1). We were able to find cranial nerve signs in two patients, and this suggested Wallenberg syndrome, resulting from vertebrobasillar insufficiencies; we found

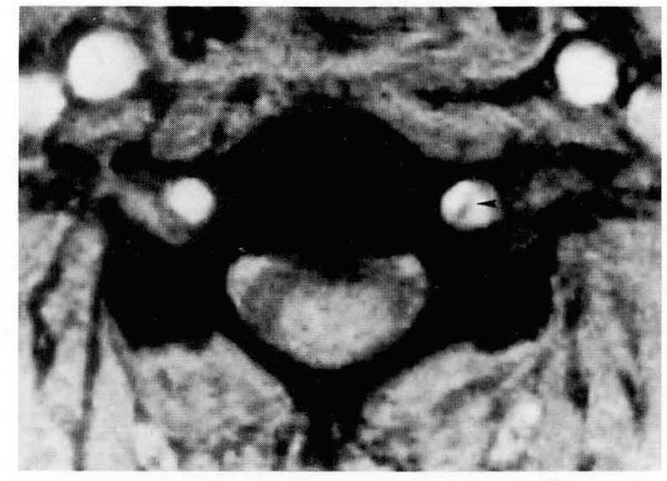

Fig. 3. Axial gradient echo MR image $\left(510 / 12 / 50^{\circ}\right)$ of a C4-5 level reveals linear, traversing, low signal suggesting intimal flap(arrowhead) in the flow related enhancement of the left vertebral artery in a 45-year-old man who showed skull fracture, epidural hematoma and fracture/dislocation of C5-6 from a fall-down trauma. three cases of brain infarction in six available brain CTs of patients with abnormal flow signal in the vertebral artery (Fig. 1), but comparative study was not possible due to the lack of data oriented to the brain problem. In addition, our patients medical records showed no specific clinical history of predisposing factors for spontaneous vertebral artery dissection.

\section{DISCUSSION}

Due to their unique anatomic location in the osteofibrous tunnel, the V2 segments of extracranial vertebral arteries are subject to damage during an episode of cervical spine trauma(9-11). MR imaging and MR angiographic findings of a damaged vessel have been well-described $(5-8)$. A recent report of MR angiographic findings revealed a considerable rate(24 $\%$ ) of vertebral artery injury after acute cervical spine trauma, although the majority of cases were clinically silent(3). Only six cases of MR angiography were included in our study, and this is insufficient data for di-

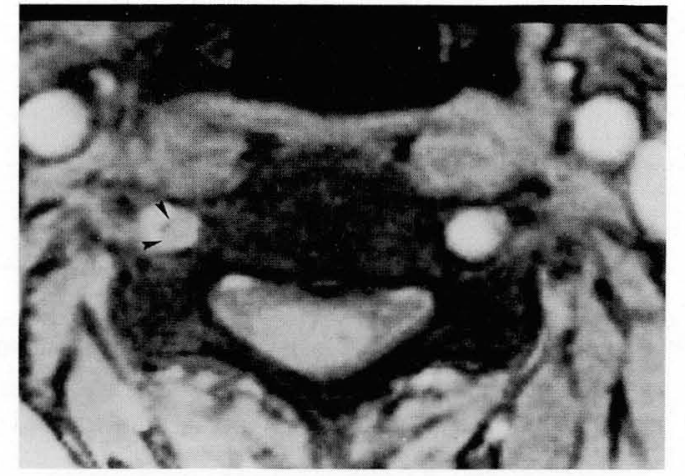

Fig. 4. Axial gradient echo MR image $\left(510 / 12 / 50^{\circ}\right)$ at $\mathrm{C}-3$ reveals eccentric narrowing of flow related signal by medial inhomogeneously high signal suggesting dissection hematoma or thrombosis(arrowheads) in a 26-year-old man who sustained posterior neck pain and revealed subluxation between $\mathrm{C} 4$ and $\mathrm{C} 5$ from vehicular trauma.

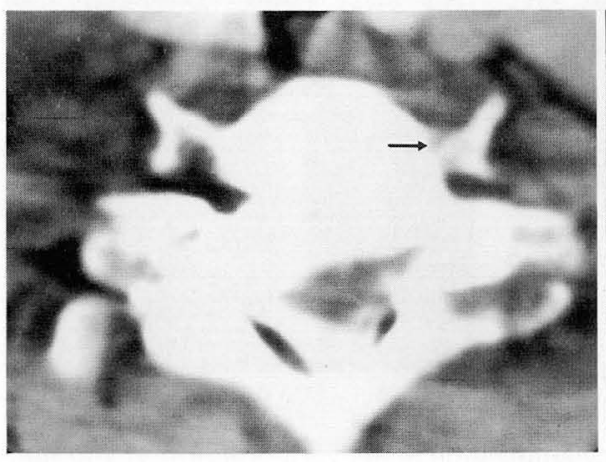

a

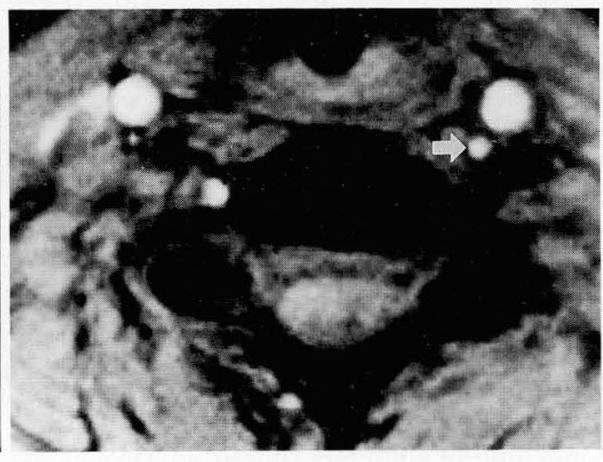

b

Fig. 5. Expelled left vertebral artery from an osteofibrous tunnel. A 33-yearold woman who sustained neck pain and numbness in all finger tips following a vehicular trauma.

a. CT image reveals C-6 left transverse process fracture(arrow) and subluxation between C- 6 and C-7.

b. Axial gradient echo(510/12/50 $)$ MR image at C-6, demonstrates anterior deviation of flow related enhancement for left vertebral artery(arrow) approximates just posterior to the left carotid artery. 
rect comparison with that of the previous report. In our study, however, statistically reliable vessel occlusions were found in only $8 / 61$ cases $(13 \%)$, which was a lower proportion than that found in MR angiographic study $(7 / 37,19 \%)$ by Friedman et al.(3). The low incidence of vessel occlusion in our study might be partially related to the long time interval(mean 27 days) between MR imaging and the traumatic event, as well as to the potential pitfall of GRE sequence in the differentiation of subacute thrombi from flowing blood(12). In many cases in our study, the observed findings of vascular lesions might be only vestigial lesions. Moreover, the poor signal intensity difference between a thrombus and the inherent magnetization susceptibility effect of the GRE sequence $(13-15)$ caused difficulty in the interpretation of mild degree narrowing of a vertebral artery and no statistically significant difference between patients and the control group might be resulted(Table 1).

Initial interpretation of MR imaging, which revealed the complete absence of one vertebral artery flow in 11 vertebral arteries in ten patients, led us to consider another possibility : severe hypoplasia or aplasia of the unilateral vertebral artery should also be considered in these cases. In CT reviews of both patients and the control group, we thus excluded the cases having definite, small unilateral transverse foramina(Table 1). Six cases of occlusion were verified by subsequent MR angiography and/or DSA studies(Fig. 1, 2).

The development of aneurysms or arteriovenous fistulas from vertebral artery injury, although rare, have been reported with increasing frequency in angiographic studies $(16,17)$. However we could not find such a case in GRE sequence and that might be partially related to the inherent difficulty in detecting a small abnormal flow signal in the GRE sequences previously discussed.

The visualization in angiography of a double lumen or intimal flap is considered by some to be pathognomonic $(18,19)$. We have suggested that this might be also applicable to MR images and found cases which on axial image directly among the patients $(n=3)$ and the control group $(n=1)$, showed intimal flap and false lumen. These cases had intraluminally traversing, linear signals in continuous multiple axial views with preserved blood flow in the false lumen(Fig. 3). We could not, however, confirm them angiographically because of the weak rationale for further angiographic studies in the clinically silent patients.

We found two patients who showed compromised flow in the narrowed vessel lumen compressed by an adjacent hematoma in its fixed position in the intact osteofibrous canal. In one other patient, a short segment of the vertebral artery was expelled from its original site in the destructed bony framework and there was no flow disturbance in that relocated vessel lumen (Fig. 5).

Conventional angiography may be the most accurate and definitive imaging modality in the diagnosis of these vessel lesions, but it cannot be justified for the screening of asymptomatic patients. In spite of the inherent dephasing and technical problems, MR angiography can be used with a high degree of reliability to show vascular narrowing or occlusion $(3,8,20)$. In statistical analysis comparing patients with the control group, the only reliable finding on axial MR images was absent or poor flow signal in the entire length of the vessel(Table 1).

This study has, in fact, several limitations. A limited number of injuries were confirmed by the generally accepted gold standard of conventional angiography ; the scanning time interval were, however, long enough (mean 27 days) for the stabilization of arterial dissection, and we were unable to recommend further practical angiographic confirmation or follow-up study for patients showing subtle changes with no vessel oriented problems. Another limitation is that most of the sagittal images of our patients were not helpful in the interpretation of vascular problem due to their discrepant plane of section regardless of the course of vertebral arteries. Thus, the GRE image of the axial plane was the only available image in the majority of our cases.

In patient's records we found several signs such as neck pain, headache, transient loss of consciousness and cord injury symptoms but in only two patients did clinical signs suggest a vessel problem. It is possible that the real posterior fossa sign, at least that relating to TIA in the acute stage of trauma, might be overlooked by the first examiner due to the general symptoms of head trauma and later due to restricted clinical expression while the patient is absolutely stabilized in bed. In spite of uncertain vessel related clinical signs, we found that patients with quadriplegia or quadriparesis, indicating more severe trauma to the bony framework, were significantly more likely to have arterial occlusions.

In conclusion, on conventional MR imaging of major cervical spine trauma patients, we found a number of cases of damage to vertebral arteries; the incidence of this was significantly related to the severity of the initial trauma. In spite of vague clinical signs of vessel injuries, MR studies (including available MR angiography) must be applied as soon as possible to patients at risk, in order to recognize a possible vertebral artery injury.

\section{REFERENCES}

1. Simeone FA, Goldberg III. Thrombosis of the vertebral artery from hyperextension injury of the neck. JNeurosurg $1968 ; 29$ : 540-544

2. Mirvis SE, Geisler FH, Jelinek JJ, et al. Acute cervical spine trauma : evaluation with 1.5-TMR imaging. Radiology 1988;166 : 807-816

3. Friedman D, Flanders A, Thomas C, Millar W. Vertebral artery injury after acute cervical spine trauma : rate of occurrence as detected by MR angiography and asessment of clinical consequences. AJR $1995 ; 164: 443-447$ 
ces. AJR $1995 ; 164: 443-447$

4. Chen J, Smith R, Keller A, Kucharczyk W. Spontaneous dissection of the vertebral artery: MR findings. J Comput Assist Tomogr $1989 ; 13: 326-329$

5. Gelbert F, Assouline E, Hodes JE, et al. MRI in spontaneous dissection of vertebral and carotid arteries. Neuroradiology 1991 ; 33:111-113

6. Sue DE, Brant-Zawadzki MN, Chance J. Dissection of cranial arteries in the neck : correlation of MRI and arteriography. Neuroradiology $1992 ; 34: 273-278$

7. Bui LN, Brant-Zawadzki M, Verghese P, Gillan G. Magnetic resonance angiography of cervicocranial dissection. Stroke 1993 ; $24: 126-131$

8. Levy C, Laissy JP, Raveau V, et al. Carotid and vertebral artery dissections: three-dimensional time-of-flight MR angiography and MR imaging versus conventional angiography. Radiology $1994 ; 190: 97-103$

9. Davis JM, Zimmerman RA. Injury of the carotid and vertebral arteries. Neuroradiology $1983 ; 25: 55-69$

10. Katirji MB, Reinmuth OM, Latchaw RE. Stroke due to vertebral artery injury. Arch Neuro/ $1985 ; 42: 242-248$

11. Alexander JJ, Glagov S, Zarins CK. Repair of a vertebral artery dissection. J Neurosurg $1986 ; 64: 663-665$

12. Yousem DM, Balakirishnan J, Debrun GM, Bryan RN. Hyperinten- se thrombus on GRASS MR images : potential pitfall in flow evaluation. AJNR 1990;11:51-58

13. Atlas SW, Mark AS, Fram EK, et al. Vascular intracranial lesions gradient echo MR imaging applications. Radiology 1988;169: $455-461$

14. Gomori JM, Grossman RI, Goldberg HI, Zimmerman RA, Bilaniuk LT. Intracranial hematomas: imaging by high-field MR. Radiology $1985 ; 157: 87-93$

15. Kwan ESK, Wolpert SM, Scott RM, Runge V. MR evaluation of neurovascular lesions after endovascular occlusion with detachableballoons. AJNR1988; $9: 523-531$

16. Rahimizadeh A, Sabouri-Daylami M, Amir-Moezi N, Haddadian K. Traumatic aneurysm of the extracranial vertebral artery. Neurosurgery $1986 ; 19: 628-630$

17. Roper PR, Guinto FC, Wolma FJ. Posttraumatic vertebral artery aneurysm and arteriovenous fistula : a case report. Surgery 1983 ; $96: 556-559$

18. Miyazaki S, Yamura A, Kamata K, Fukushima H. A dissecting aneurysm of the vertebral artery. Surg Neuro/1984;21:171-174

19. Waga S, Fujimoto K, Morooka Y. Dissection aneurysm of the vertebral artery. Surg Neurol 1978;10:237-239

20. Flanders AE, Tartaglino LM, Friedman DP, Aquilone LF. Magnetic resonance imaging in acute spinal injury. Semin Roentgenol $1992 ; 27: 271-298$

대 한 방사 선의 학회 지 $1996: 35(5): 667 \sim 672$

\title{
경추외상환자에서 발생한 추골동맥손상의 자기공명영상-1
}

\author{
1 연세대학교의과대학 진단방사선과학교실 \\ 2 연세대학교 의과대학 신경외과학교실
}

\section{유정식 · 정태섭 · 김영수 ${ }^{2} \cdot$ 조용은 $^{2} \cdot$ 강병철 · 김동익}

목 적 : 경추외상에 의해 초래되는 추골동맥의 손상에 대해 자기공명영상을 이용한 진단의 효용성을 알아보기 위함이다.

대상 및 방법 : 경추외상환자 63명에서 고식적 자기공명영상에 나타난 추골동맥손상의 양상을 알아보고 대조군 63 명의 자기공 명영상과 비교하여 통계학적으로 의의가 있는 추골동맥의 변화를 규명해 보고자 하였다. 또한, 경추손상의 정도와 추골동맥손상 과의 상호연관성을 알아보고자 경추 단순촬영, $\mathrm{CT}$, 임상증상에 대한 비교분석을 시도하였다.

결 과 : 8 명의 환자에서 9 개의 추골동맥에 정상적인 혈류에 의한 신호강도가 보이지 않았으며 대조군에서는 1 예에 불과하여 통계학적인 의의가 있었다 $(p<.02)$. 혈관내벽의 열상을 시사하는 혈관내 선상 신호나 혈관의 부분적인 내경감소는 환자군에서 더 높은 빈도로 관찰되었지만 통계학적인 의의는 없었다. 척수손상의 정도가 심할수록 혈관폐쇄의 빈도가 높았다 $(p<.02)$.

결 론 : 고식적 자기공명영상은 경추외상환자에서의 추골동맥손상을 발견해내고 평가하는데 유용한 진단방법이다. 